\title{
Pendampingan Operasional Bank Syariah Di Masa Pandemi Covid-19
}

\author{
Ahmad Khoirudin ${ }^{1}$, Jefik Zulfikar Hafizd ${ }^{2 *}$ \\ IAIN Syekh Nurjati Cirebon \\ 1e-mail: chaerudin.ahmed@ gmail.com \\ 2e-mail: hafizd.zulfikar@gmail.com \\ *Corresponding Author
}

\begin{abstract}
ABSTRAK
Program kegiatan pengabdian ini bertujuan untuk melakukan pendampingan operasional Bank Muamalat KCP Majalengka dalam rangka dapat meningkatkan kinerja di masa adaptasi kebiasaan baru setelah sebelumnya sempat tidak beroperasi karena pandemi. Berdasarkan program kegiatan pengabdian ini, masih ditemukan batasan dalam kegiatan operasional di masa pandemi COVID19 seperti penerapan protokol kesehatan dan penerapan WFH (Work From Home) bagi 50\% pegawai bank dengan jadwal bergantian. Kegiatan pendampingan operasional bank Muamalat KCP Majalengka cukup membantu pelaksanaan kegiatan yang sebelumnya tertunda karena adanya pembatas aktivitas bank. Dalam rangka tindak lanjut kegiatan pendampingan diperlukan kerjasama yang lebih intensif antara IAIN Syekh Nurjati dengan Bank Muamalat KCP Majalengka.
\end{abstract}

Kata Kunci: Pendampingan Operasional, Bank Syariah, Pandemi COVID-19

\begin{abstract}
This service activity program aims to provide operational assistance to Bank Muamalat KCP Majalengka in order to improve performance during the adaptation period of new habits after previously being inoperative due to the pandemic. Based on this program of service activities, there are still limitations in operational activities during the COVID-19 pandemic such as the application of health protocols and the application of WFH (Work From Home) for $50 \%$ of bank employees with alternate schedules. The operational assistance activities of the Bank Muamalat KCP Majalengka are sufficient to assist the implementation of activities that were previously delayed due to restrictions on bank activities. In order to follow up the assistance activities, more intensive collaboration between IAIN Syekh Nurjati and Bank Muamalat KCP Majalengka is required.
\end{abstract}

Keywords: Operational Assistance, Islamic Banking, The COVID-19 Pandemic 


\section{PENDAHULUAN}

Pada tahun 2020 dunia dikejutkan dengan adanya situasi yang cukup genting dan berdampak pada ekonomi termasuk dunia perbankan. Pandemi COVID-19 mengakibatkan beberapa perbankan syariah mengalami penurunan jumlah kegiatan operasional. Beberapa risiko yang akan timbul dari beberapa faktor termasuk risiko operasional yang akan terjadi. Risiko operasional bisa terjadi karena ada gangguan terhadap sumber daya manusia (SDM) sebagai kontributor kinerja utama dari sisi internal perbankan syariah maupun kepada nasabah sebagai kontributor eksternal (Fauziah, Fakhriyah, \& Abdurrohman, 2020). Berbagai kebijakan diberlakukan dalam rangka mengatasi penyebaran COVID-19, seperti physical distancing, pemakaian masker dan pembatasan sosial berskala besar (PSBB). Kegiatan tersebut berakibatnya pada penurunan aktivitas masyarakat yang berakibat pada menurunnya sektor ekonomi Indonesia (Hafizd, 2020).

Bank Muamalat merupakan salah satu lembaga keuangan yang terdampak pandemi COVID-19. Kegiatan operasional bank sempat dihentikan untuk mencegah penyebaran virus. Pembatasan Sosial Berskala Besar (PSBB) menjadikan kegiatan bank tidak bisa dilakukan secara normal. Aktivitas yang biasa dilakukan secara langsung dengan banyak orang harus di minimalisir. Di sisi lain bank perlu terus melakukan aktivitas agar bisa bertahan sehingga tidak mengalami kerugian. Aspek intermediasi bank mengalami penurunan baik dari sisi penerimaan dana pihak ketiga (DPK) maupun penyaluran dana melalui pembiayaan.

Pengelolaan operasional bank perlu dilakukan dengan langkah yang tepat agar dapat menyeimbangkan antara pencapaian kepentingan bank dengan kepentingan menjaga kesehatan (Hafizd, 2020). Pandemi berdampak terhadap aktivitas Bank Muamalat meliputi kewajiban menjalankan secara maksimal protokol kesehatan dan kewajiban memberikan keringanan kepada nasabah terdampak pandemi untuk menunda pembayaran sebagaimana diatur oleh PJOK Nomor 11/POJK.03/2020 (OJK, 2020). Protokol kesehatan cukup membatasi aktivitas operasional bank namun dalam rangka menjunjung kemanusiaan maka kebijakan tersebut perlu dilaksanakan. Kegiatan berupa pendampingan operasional pada Bank Muamalat KCP Majalengka bisa sangat membantu penyelesaian pekerjaan yang tertunda akibat pembatasan aktivitas bank. Selain itu diskusi akademis terkait kegiatan operasional bank bisa memberikan solusi untuk pengembangan bank maupun penyelesaian persoalan yang ada. 


\section{BAHAN DAN METODE}

Perbankan adalah segala sesuatu yang menyangkut tentang bank, mencakup kelembagaan, kegiatan usaha, serta cara dan proses dalam melaksanakan kegiatan usahanya. Bank adalah badan usaha yang menghimpun dana dari masyarakat dalam bentuk simpanan dan menyalurkannya kepada masyarakat dalam bentuk kredit dan atau bentuk-bentuk lainnya dalam rangka meningkatkan taraf hidup rakyat banyak (DPR \& Presiden, 1998). Perbankan Syariah adalah segala sesuatu yang menyangkut tentang Bank Syariah dan Unit Usaha Syariah, mencakup kelembagaan, kegiatan usaha, serta cara dan proses dalam melaksanakan kegiatan usahanya (DPR \& Presiden, 2008). Pada dasarnya kegiatan bank merupakan hal yang diperbolehkan akan tetapi unsur bunga pada bank konvensional merupakan hal yang tidak bisa diterima dalam Islam. Bank syariah menawarkan solusi permasalahan bunga. Keuntungan bank tidak ditetapkan atas pokok hutang tetapi di sepakati berdasarkan bagi hasil akad yang dilakukan.

Bank Muamalat Indonesia (BMI) merupakan Bank Syariah pertama di Indonesia yang berdiri pada 1 November 1991 dan beroperasi pada 1 Mei 1992. Pendirian BMI dipeloporan oleh Mejelis Ulama Indonesia (MUI), Ikatan Cendekiawan Muslim Indonesia (ICMI), dan pengusaha muslim yang kemudian mendapat dukungan dari Pemerintah Republik Indonesia. BMI melakukan banyak terobosan dan inovasi produk keuangan menjadi berlandaskan syariah. Produk-produk BMI menjadi tonggak sejarah penting industri perbankan syariah. BMI memiliki 325 kantor layanan termasuk 1 (satu) kantor cabang di Malaysia. Operasional BMI didukung oleh 710 unit ATM Muamalat, 120.000 jaringan ATM Bersama dan ATM Prima, serta lebih dari 11.000 jaringan ATM di Negara Malaysia. BMI memiliki Visi menjadi bank syariah terbaik di Indonesia. BMI masuk dalam 10 besar bank dengan pengakuan eksistensi pada tingkat regional. BMI memiliki Misi membangun lembaga keuangan syariah yang unggul dan berkesinambungan dengan penekanan pada semangat kewirausahaan berdasarkan prinsip kehati-hatian, keunggulan sumber daya manusia yang islami dan profesional serta orientasi investasi yang inovatif, untuk memaksimalkan nilai kepada seluruh pemangku kepentingan (Bank Muamalat, 2016). Sebagai lembaga perbankan, bank Muamalat diatur dan diawasi oleh Bank Indonesia (BI) dan Otoritas Jasa Keuangan (OJK). Selain itu setiap kegiatan bank Muamalat harus dilaksanakan berdasarkan fatwa Dewan Syariah Nasional Majeleis Ulama Indonesia (DSN-MUI).

Bank Muamalat Kantor Cabang Pembantu (KCP) Majalengka merupakan lembaga pelayanan jasa keuangan yang berbasis syariat Islam. Bank Muamalat KCP Majalengka pertama kali berdiri tahun 2010 di Jl. K.H.Abdul Halim, No. 81 Majalengka. Bank Muamalat KCP Majalengka memiliki visi menjadi bank syariah utama di Indonesia, dominan di pasar spiritual, dan dikagumi di pasar rasional. Bank Muamalat KCP Majalengka memiliki Misi menjadi role 
model lembaga keuangan syariah dunia dengan penekanan pada semangat kewiraushaan, keunggulan manajemen, dan orientasi investasi yang inovatif untuk memaksimalkan nilai kepada seluruh pemangku kepentingan.

Bank syariah memiliki fungsi intermediasi yakni penghimpunan dana dari masyarakat dan pembiayaan. Bank Muamalat KCP Majalengka memiliki tiga jenis produk yakni produk terkait penghimpunan dana, produk pembiayaan, dan produk pelayanan jasa bank. Bank Muamalat menghimpun dana dengan bentuk titipan melalui akad Wadi'ah dan bentuk investasi melalui akad Mudharabah (Bank Muamalat, 2016). Wadi'ah merupakan akad antara nasabah dengan bank, sedangkan mudharabah yaitu akad antara pemilik dana yang menginvestasikan dananya dengan pihak bank yang menerima dana untuk dimanfaatkan berdasarkan ketentuan yang tidak bertentangan dengan syariat Islam (Ismail, 2017).

Bank Muamalat KCP Majalengka menawarkan produk tabungan, pembiayaan, dan pelayanan jasa. Bank Muamalat menawarkan berbagai produk untuk menghimpun dana dengan tabungan, giro dan deposito seperti:

1. Tabungan iB Hijrah Haji,

2. Tabungan iB Hijrah,

3. Tabungan iB Hijrah Valas,

4. TabunganKu,

5. Tabungan iB Hijrah Rencana,

6. Tabungan iB Hijrah Prima,

7. Tabungan iB Simpel,

8. Giro iB Hijrah Attijary,

9. Giro iB Hijrah Ultima, dan

10. Deposito iB Hijrah.

Dalam rangka kegiatan penyaluran dana untuk memperoleh keuntungan, bank Muamalat menawarkan produk:

1. KPR iB Muamalat,

2. Pembiayaan iB Muamalat Pensiun, dan

3. Pembiayaan iB Muamalat Multiguna.

Dalam rangka menunjang terpenuhinya kebutuhan nasabah, Bank Muamalat menawarkan produk pelayanan jasa meliputi:

1. Kartu Shar-E Debit Gold,

2. Kartu Shar-E Debit Classic,

3. Kartu Shar-E Debit 1HRAM, 
4. Kartu Shar-E Debit Prioritas, dan

5. E-Banking.

Kegiatan operasional Bank Muamalat KCP Majalengka dijalankan oleh jajaran pimpinan dan pegawai. Adapun Struktur Organisasi Bank Muamalat KCP Majalengka adalah sebagai berikut ${ }^{1}$ :

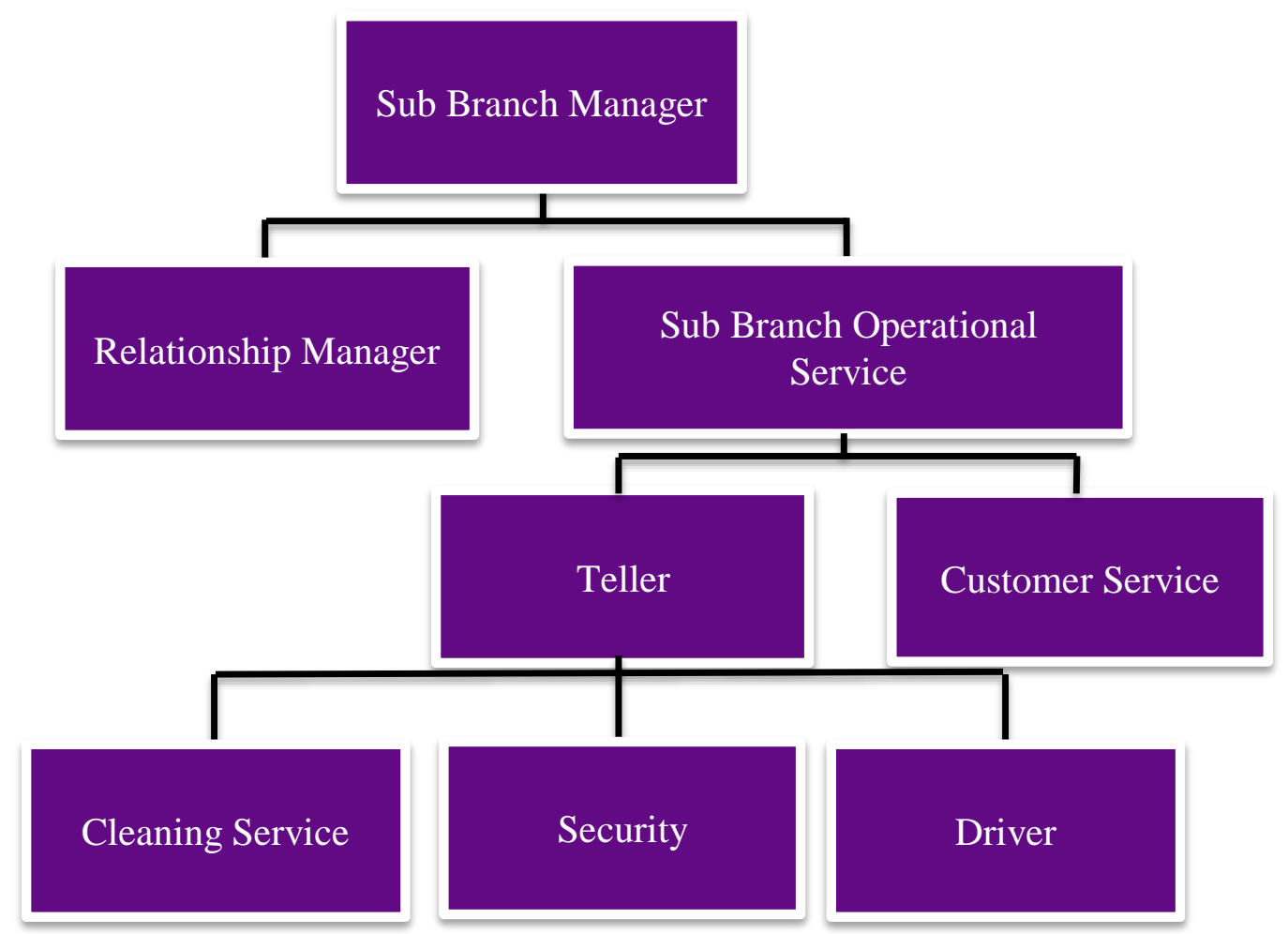

Gambar. 1 Stuktur Organisasi Bank Muamalat KCP Majalengka

1. Sub Branch Manager

Sub Branch Manager memimpin dan bertanggung jawab terhadap pencapaian kinerja dan pengelolaan bisnis, serta segala aktivitas kegiatan operasional Kantor Cabang Pembantu (Sub Branch), terutama dalam hal kegiatan sales, dan operasional, sehingga dapat mencapai target sesuai dengan kebijakan dan strategi yang telah ditetapkan dalam rangka memberikan kontribusi dan keuntungan yang maksimal bagi Bank Muamalat Indonesia. Sub Branch Manager memimpin dan bertanggung jawab terhadap pencapaian kinerja dan pengelolaan bisnis, memastikan tercapainya target bisnis, melakukan Cost Control atas semua biaya serta melakukan pengawasan terhadap seluruh kegiatan operasional (penjualan, pelayanan, dan operasional) di KCP Majalengka agar sistem dan prosedur berjalan sesuai yang ditetapkan.

\footnotetext{
${ }^{1}$ Wawancara dengan Ibu Esi selaku Sub Branch Manager dan Pak Dery selaku Relationship Manager di Bank Muamalat KCP Majalengka pada tanggal 25 September 2020
} 
2. Relationship Manager

Relationship Manager menjalankan aktivitas pencapaian target bisnis produk Funding di KCP Majalengka dengan mengacu pada prosedur yang berlaku guna memberikan kontribusi dan keuntungan yang maksimal bagi lembaga. Relationship Manager menjalankan proses penjualan produk Funding kepada nasabah atau calon, membina relasi dan memberikan pelayanan yang baik untuk menjaga customer loyalty dan membuka peluang mendapatkan referensi calon nasabah. Relationship Manager mencatat aktivitas pencapaian target pada sistem dan prosedur yang berlaku guna mendukung pencapaian dan pertumbuhan bisnis Funding.

3. Sub Branch Operation Service

Sub Branch Operation Service memiliki tanggung jawab utama antara lain memastikan keadaan kantor aman dan sesuai dengan SOP, mengawasi kinerja operation (Teller \& CS), mengesahkan setiap transaksi operasional, mengawasi penggunaan sarana kantor, mendukung kinerja bisnis agar sesuai peraturan operasional, dan memastikan kondisi keuangan Vault Khasanah agar tidak melebihi dari Rp 700.000.000. Selain itu Sub Branch Operation Service bisa menggantikan jabatan SBOS di Kantor Cabang atau di Kantor Cabang Pembantu lain.

4. Customer Service

Customer Service melakukan penawaran produk kepada Nasabah serta memberikan pelayanan dan melakukan pengadministrasian, mendokumentasikan dan kegiatan yang berkaitan dengan transaksi pelayanan kepada Nasabah. Customer Service bertanggung jawab memastikan seluruh hak dan kewajiban Nasabah telah diketahui dan dipahami oleh Nasabah. Apabila ada keluhan atau pengaduan nasabah maka Customer Service bertugas untuk menyelesaikannya. Customer Service bertugas mengelola dan mengadministrasikan aktivitas yang berkaitan dengan penerimaan BPIH, menjalankan ketentuan tentang Know Your Customer (KYC), pengkinian data nasabah, complaint tracking, mengurus prudencial banking, serta menjalankan fungsi petugas frontlines lainnya. Customer service bisa menjadi petugas pemegang kunci tombak untuk lemari uang/brankas dan ATM serta melakukan dua control atas transaksi teller.

5. Teller

Teller melayani Nasabah dalam bertransaksi baik penarikan, setoran, pemindahbukuan, transfer antar bank baik secara tunai dan non tunai serta melakukan cash management terhadap ketersediaan uang tunai pada vault dan ATM guna mendukung kelancaran operasional bisnis dan pelayanan prima terhadap kepada Nasabah. Teller bertanggung jawab memastikan kesesuaian antara tiket transaksi dengan sistem, memastikan 
semua perlengkapan Teller berfungsi, menjaga penampilan fisik dan area kerja (meja Teller, baju, ID Card), menghitung, memverifikasi dan mengidentifikasi uang, slip dan tanda tangan, serta menjelaskan fungsi petugas frontlines lainnya saat petugas frontlines lainnya berhalangan hadir.

6. Cleaning Service

Cleaning Service memiliki tanggung jawab utama membersihkan dan merapikan seluruh area bank, menyiapkan konsumsi untuk pegawai, mentaati peraturan-peraturan yang telah diberikan oleh managemen serta membantu pegawai untuk kegiatan di luar kantor, seperti mengirimkan paket dan lain-lain.

7. Security

Security memiliki tanggung jawab untuk menjaga keamanan dan memastikan area banking aman terkendali secara keseluruhan. Pada saat jam operasional, security stand by menjaga dan membukakan pintu untuk nasabah. Selain itu area parker mobil dan motor nasabah diawasi oleh security.

8. Driver

Driver memiliki tanggung jawab memastikan mobil dalam keadaan bersih, merawat mesin mobil, mengecek pemakaian olie, memperbaiki kerusakan kecil dan jika diperlukan dibawa ke bengkel dengan koordinasikan ke bagian Administrasi. Saat di perjalanan Driver perlu memastikan pengemudi dan penumpang mengenakan sabuk pengaman selama perjalanan luar, memastikan mobil diparkir ditempat yang aman dan terkunci, mengendarai kendaraan dengan baik mengikuti rambu-rambu lalu lintas. Secara administrative driver perlu memeriksa STNK kendaraan dan memberitahukan ke bagian Administrasi sebulan sebelum jatuh tempo perpanjangan, selain itu Driver harus memiliki SIM tipe A yang berlaku serta mengisi laporan aktivitas pengemudi yang dilaporkan setiap bulan.

Bank Muamalat KCP Majalengka melakukan kegiatan intermediasi yakni penghimpunan dana dari masyarakat dan pembiayaan. Kegiatan bank dilaksanakan oleh 8 orang pegawai termasuk pimpinan Bank Muamalat KCP Majalengka. Jam operasional selama pandemi COVID-19 bank yakni Senin-Jumat dari pukul 09.00-15.00 WIB. Bank Muamalat KCP Majalengka menerapkan budaya kerja yang menjunjung akhlaqul karimah dengan menerapkan prinsip Islami, Modern, dan Profesional (IDEAL).

Pendampingan ini merupakan kegiatan pengabdian yang dilakukan oleh tim yang terdiri atas dosen dan mahasiswa. Kegiatan ini bertujuan untuk mendukung operasional bank Muamalat KCP Majalengka bersamaan dengan pelaksanaan program Praktik Pengalaman Lapangan (PPL) Mahasiswa Fakultas Syariah dan Ekonomi Islam IAIN Syekh Nurjati 
Cirebon. Jenis pengabdian kegiatan dilakukan melalui pendampingan operasional Bank Muamalat dari dalam rangka adaptasi kebiasaan baru setelah sebelumnya sempat tidak beroperasi karena pandemi. Kegiatan dilaksanakan mulai bulan Agustus hingga Oktober 2020. Berikut merupakan metode penerapan program kegiatan pengabdian ini:

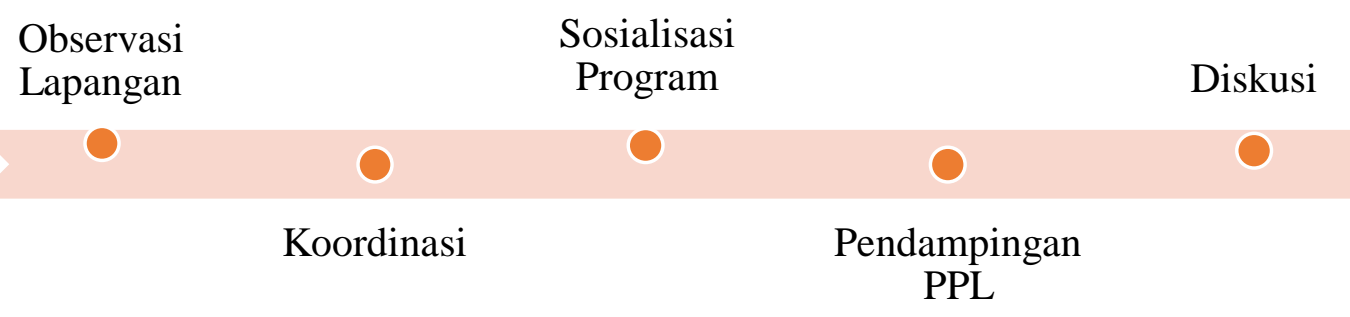

Gambar. 2 Metode Penerapan Program Kegiatan

Kegiatan pendampingan operasional Bank Muamalat KCP Majalengka dilakukan melalui metode diskusi dan tanya jawab. Kegiatan pendampingan dimulai dengan observasi lokasi Bank Muamalat, koordinasi dengan pimpinan, sosialisasi program pendampingan, praktik pengalaman lapangan dan diskusi. Target output pelaksanaan kegiatan pendampingan ini adalah untuk mendukung kegiatan Bank Muamalat KCP Majalengka di tengah masa pandemi dan untuk mendukung kegiatan praktik pengalaman lapangan mahasiswa.

\section{HASIL DAN PEMBAHASAN}

Peran akademisi sangat diperlukan Bank Muamalat untuk dapat bersinergi dalam mengembangkan perbankan syariah. Kegiatan Pendampingan Operasional Bank Muamalat KCP Majalengka dilaksanakan bersamaan dengan kegiatan Praktik Pengalaman Lapangan (PPL) Mahasiswa Jurusan Perbankan Syari'ah di Fakultas Syariah dan Ekonomi Islam IAIN Syekh Nurjati Cirebon. Kegiatan pendampingan meliputi beberapa tahapan kegiatan, dimulai dengan observasi lapangan untuk mengetahui kondisi yang ada di lapangan. Setelah kondisi diketahui, dosen dan mahasiswa melakukan koordinasi dengan pihak Bank Muamalat KCP Majalengka. Halhal yang dibahas adalah tentang waktu dan tempat pelaksanaan program pendampingan operasional bank syariah, pelaksanaan PPL, dan diskusi, bagaimana proses kegiatan yang akan dilakukan, serta persiapan apa saja yang diperlukan untuk menyelenggarakan kegiatan tersebut.

Setelah pelaksanaan koordinasi Koordinasi, tim pelaksana program pengabdian melakukan sosialisasi rencana program-program kegiatan yang telah dirumuskan sebelumnya kepada pihak Bank Muamalat KCP Majalengka. Sebagai bagian dari tim pengabdian, Dosen memberikan pembekalan Praktik Pengalaman Lapangan (PPL) kepada mahasiswa untuk menambah kesiapan 
dalam melaksanakan kegiatan PPL. Setiap kegiatan mahasiswa sepenuhnya diawasi oleh Dosen selaku pembimbing dalam kegiatan PPL. Adapun materi yang diberikan mencakup:

1. Teknik dan tatacara pelaksanaan Praktik Kerja Lapangan di Bank Muamalat;

2. Tata pelayanan operasional dan pemasaran di Bank Bank Muamalat;

3. Produk dan aplikasi akad di Bank Muamalat; dan

4. Teknik penyusunan laporan.

Kegiatan PPL mencakup operasionalisasi perbankan, manajemen perbankan, produk perbankan, simulasi perbankan dan tata cara pembuatan laporan kegiatan. Operasionalisasi Perbankan adalah segala aktivitas yang diselenggarakan oleh perbankan, baik yang menyangkut masalah front office (customer service, teller, dan layanan lainnya), maupun back office (bagian kredit/pembiayaan, accounting, kontrol, administrasi, dan lainnya). Sehubungan dengan operasionalisasi perbankan, mahasiswa menjalankan kegiatan sebagai berikut:

1. Mengamati dan mendampingi pegawai Bank Muamalat bila memungkinkan tanpa mengganggu proses kegiatan;

2. Memahami secara umum unit-unit yang ada dalam Bank Muamalat serta tugas-tugasnya;

3. Mengikuti jadwal kegiatan di Bank Muamalat selama satu bulan;

4. Mencatat hasil temuan sebagai laporan dan mengkomunikasikan kepada pihak Bank Muamalat; dan

5. Mengikuti aturan dan kode etik yang berlaku di Bank Muamalat.

Sehubungan dengan manajemen dan prinsip operasionalisasi perbankan, mahasiswa menjalankan kegiatan mencatat hal yang terkait dengan manajemen Bank Muamalat sesuai dengan hasil temuan dan mencatat tentang prinsip-prinsip operasionalisasi Bank Muamalat berdasarkan penjelasan dari pimpinan bank. Sehubungan dengan produk Bank Muamalat, mahasiswa mencatat produk yang diterapkan Bank Muamalat serta mencatat hasil temuan di lapangan sebagai laporan akhir dan dapat dijadikan sebagai lanjutan penelitian.

Kemudian tim pelaksana program pengabdian mendampingi Bank Muamalat KCP Majalengka dalam melaksanakan kegiatan operasional selama satu bulan. Program kegiatan pengabdian disertai dengan diskusi intensif antara tim pelaksana dengan perwakilan pegawai Bank Muamalat KCP Majalengka. Kegiatan diskusi membahas seputar kondisi bank, kegiatan pemasaran dan operasional bank, keunggulan dan kekurangan bank, serta bagaimana strategi pengembangan bisnis bank.

Pengembangan usaha Bank Muamalat KCP Majalengka dapat dilakukan dengan sosialisasi kepada masyarakat dengan membangun kepercayaan. Kepercayaan merupakan modal penting untuk mempertahankan nasabah dan merekrut nasabah baru. Selain itu peningkatan kualitas 
pelayanan dapat memberikan pengaruh positif terhadap penambahan jumlah nasabah. Sebagai bentuk tanggung jawab kepada masyarkat, Bank Muamalat telah memenuhi aspek legal dan prinsp syariah dalam seluruh kegiatan perbankan. Sedangkan pada aspek ekonomi, Bank Muamalat menghadapi berbagai risiko operasional.

Risiko operasional merupakan risiko yang disebabkan oleh berbagai faktor terutama sumber daya manusia (SDM) sebagai kontributor kinerja utama. SDM yang berasal dari internal bank adalah pegawai dan yang berasal dari eksternal bank adalah nasabah. Masalah operasional yang terjadi dikelompokkan menjadi dua yaitu masalah yang dihadapi nasabah dan masalah yang dihadapi bank (Fauziah et al., 2020). Masalah bagi nasabah yang terjadi yakni penutupan sementara kantor yang pernah terjadi dan pembatasan kantor layanan sehingga pelayanan $\mathrm{KCP}$ dihentikan untuk sementara. Sedangkan masalah bank yang terjadi yakni meningkatnya beban operasional karena penyediaan handsanitizer, masker, multivitamin, desinfektan dalam jumlah banyak untuk menjaga kesehatan lingkungan kantor terutama bagi pegawai dan nasabah. Penurunan laba bank bahkan terjadi mengingat pembatasan kegiatan serta pembatasan daerah prospek sehingga marketing tidak bisa bekerja secara optimal. Bank terhambat oleh kebijakan penerapan WFH (Work From Home) bagi 50\% pegawai bank dengan jadwal bergantian. Bank Muamalat memiliki komitmen tinggi untuk menjaga protokol kesehatan nasabah dan pegawai.

Isu krisis yang bisa berdampak pada perbankan perlu dihadapi dengan langkah yang solutif. Solusi yang bisa dilakukan di masa pandemi COVID-19 adalah dengan memikat nasabah atau calon nasabah dengan penawaran dan ajakan melalui media sosial seperti Facebook, Whatsapp, Website, Instagram dan lain-lain. Selain itu bisa juga melalui telepon dan datang langsung ke kediaman nasabah sambil bersilaturahmi. Nasabah perlu diberi penawaran produkproduk yang memudahkan nasabah seperti mobile banking. Bank Muamalat perlu menghimbau nasabah agar nasabah beralih menggunakan transaksi digital yang memiliki kelebihan seperti kemudahan akses di mana saja secara daring yang lebih praktis ketika ingin transfer karena tidak perlu datang langsung ke bank atau ATM sehingga kontak dengan orang lain dapat di minimalisir.

Di akhir kegiatan pendampingan, tim pelaksana program pengabdian melakukan evaluasi bersama mengenai langkah-langkah apa saja yang bisa dilakukan agar bank bisa beradaptasi dengan kebiasaan baru. Kerja sama yang lebih intensif antara IAIN Syekh Nurjati dengan Bank Muamalat KCP Majalengka perlu dilakukan agar perkembangan keilmuan di kampus bisa disinergikan dengan praktik di lapangan. 


\section{KESIMPULAN DAN SARAN}

Kegiatan pendampingan operasional Bank Muamalat KCP Majalengka telah terlaksana sebagaimana yang direncanakan. Kegiatan ini dilakukan sebagai bentuk pengabdian tim yang terdiri atas dosen dan mahasiwa. Kegiatan ini bertujuan untuk mendukung operasional bank Muamalat KCP Majalengka bersamaan dengan pelaksanaan program Praktik Pengalaman Lapangan (PPL) Mahasiswa Fakultas Syariah dan Ekonomi Islam IAIN Syekh Nurjati Cirebon. Target output pelaksanaan kegiatan pendampingan telah tercapai dengan baik. Setelah kegiatan terlaksana ditemukan bahwa masih ada batasan dalam kegiatan operasional di masa pandemi COVID-19 seperti penerapan protokol kesehatan dan penerapan WFH (Work From Home) bagi $50 \%$ pegawai bank dengan jadwal bergantian. Kegiatan pendampingan operasional bank Muamalat KCP Majalengka cukup membantu kegiatan operasional yang sebelumnya sempat tertunda karena adanya pembatas dengan bergabungnya peserta praktik pengalama lapangan (PPL) yang dibimbing oleh Dosen Fakultas Syariah dan Ekonomi Islam IAIN Syekh Nurjati Cirebon. Dalam rangka tindak lanjut kegiatan pendampingan diperlukan kerja sama yang lebih intensif antara IAIN Syekh Nurjati dengan Bank Muamalat KCP Majalengka.

Bank Muamalat KCP Majalengka bisa melakukan berbagai strategi pamasaran, sosialisasi kepada masyarakat, dan optimalisasi pemanfaatan Internet Banking mengingat potensi transaksi digital sangat besar. Dalam rangka meningkatkan pangsa pasar, Bank Muamalat KCP Majalengka bisa fokus pada generasi milenial yang dalam beberapa tahun ke depan diperkirakan bisa menjadi pelaku utama sektor ekonomi di Indonesia.

\section{UCAPAN TERIMA KASIH}

Ucapan terima kasih kami sampaikan kepada segenap jajaran Bank Muamalat KCP Majalengka. Semoga kegiatan pendampingan yang telah dilakukan dapat memberi kontribusi dan manfaat bagi Bank Muamalat, Civitas Akademik IAIN Syekh Nurjati Cirebon, dan masyarakat Indonesia.

\section{DAFTAR PUSTAKA}

Bank Muamalat. (2016). Bank Muamalat Indonesia. Retrieved October 31, 2020, from PT Bank Muamalat Tbk. website: https://www.bankmuamalat.co.id/

DPR, \& Presiden. Undang-Undang Nomor 10 Tahun 1998 tentang Perubahan Undang-Undang Nomor 7 Tahun 1992 tentang Perbankan. , (1998).

DPR, \& Presiden. Undang-Undang Republik Indonesia Nomor 21 Tahun 2008 Tentang

Perbankan Syariah. , (2008). 
Fauziah, H. N., Fakhriyah, A. N., \& Abdurrohman, A. (2020). Analisis Risiko Operasional Bank Syariah Pada Masa Pandemi Covid-19. Al-Intaj Jurnal Ekonomi Dan Perbankan Syariah, $6(2), 38-45$.

Hafizd, J. Z. (2020). Peran Bank Syariah Mandiri (BSM) Bagi Perekonomian Indonesia Di Masa Pandemi COVID-19. Al-Mustashfa: Jurnal Penelitian Hukum Ekonomi Syariah, 5(2), 138148.

Ismail. (2017). Perbankan Syariah. Jakarta: Kencana.

OJK. (2020). Peraturan OJK Nomor 11/POJK.03/2020 Tentang Stimulus Perekonomian Nasional Sebagai Countercyclical Dampak Penyebaran Coronavirus Disease 2019. 2019. https://doi.org/10.1017/CBO9781107415324.004 